\title{
Reinforcement of Culture-Based Local Wisdom through Character Education in School Children in Tenganan Pagringsingan Village Karangasem Regency
}

\author{
I Nyoman Sueca ${ }^{1}$, Ni Ketut Sreie Kusuma Wardhani ${ }^{2}$, I Nyoman Temon Astawa ${ }^{3}$ \\ \{inyomansueca64@gmail.com ${ }^{1}$ \} \\ ${ }^{1,2,3}$ Dharma Acarya Faculty, Institut Hindu Dharma Negeri Denpasar, Bali, Indonesia
}

\begin{abstract}
The development of the potential of school children can be carried out by teachers through character education by reinforcing local wisdom. In general, this study aimed to reveal and analyze the facts about the reinforcement of culture-based local wisdom through character education in school children in Tenganan Pagringsingan, Karangasem holistically and comprehensively in accordance with the tradition of Hinduism education. The method was used to support the research process, starting from preparation, and implementation until the research ends and produce a scientific work that is recognized as true. The types of data collected in this study were qualitative data. Data analysis techniques used were descriptive techniques through three activities, namely data collection, data reduction, data presentation, and conclusion or verification. Reinforcement of local wisdom in Tenganan Pagringsingan Village can be sustainable until now based on the forms of mutual cooperation, exemplary, professional, and independence and the process of planting character values in children carried out by community leaders and religious leaders with the concept of Hindu teachings contained in the teachings Tri Hita Karana, aims to improve sradhabhakti and to instill moral values as the inheritance of their ancestors.
\end{abstract}

Keywords: Reinforcement of local wisdom, character education

\section{INTRODUCTION}

The moral crisis is still a very serious problem for the Indonesian nation. Various news, both released by printed and electronic media, proclaim the decline of the morality of the nation's children, this can be seen by the rampant fights or brawls between villages, students and students as already entrenched. In addition to brawls, the trend of unlimited interaction coupled with free sex, for some elements of the nation's children has become commonplace.

On the other hand the culture of violence does not only come from students, but also from their other environments. In this case school children are victims. To minimize all forms of violence that exist in society, the role of parents and families is very dominant in preventing all forms of violence for the convenience of school children. Ideally the family will be a safe and comfortable place for children. While the school is a place where children can go through 
the development process and nurture their various potentials with joy and excitement. Supposedly, parents feel calm leaving their children without any anxiety and worries.

The development of the potential of school children can be done by teachers through character education by strengthening local wisdom. Local wisdom is an intelligence possessed by certain ethnic groups, which is obtained through ethnic experience that grapples with their environment. Local wisdom is an ancestral inheritance related to the values of life [1]. The values of life are united not only in terms of religion, but also in culture, and customs [2]. When a society adapts to its environment, they develop wisdom whether in the form of knowledge or ideas, equipment, combined with customary norms, cultural values, environmental management activities to meet their daily needs.

The nature of local wisdom according to Law Number 32 of 2009 is the noble values that apply in the order of people's lives. These noble values include protecting and managing the environment sustainably. Local wisdom is the result of a process of adaptation for generations in a very long period of time towards a natural environment of residence. Local wisdom is generally in the form of oral and written in a community social system. Local wisdom is closely related to geographical conditions or the natural environment with values that can be the main capital in building a community.

The characteristics of local wisdom include the ability to survive against the culture of the outside, to accommodate elements of external culture, to integrate outside cultural elements into the original culture, to control culture, and to give direction to cultural development. The function of local wisdom is to conserve the value of inheritance and the preservation of natural resources, to develop human resources, and to develop culture and science and noble values to protect and manage the environment as noble characters.

One of the noble characters that must be internalized towards students according to the Ministry of Education and Culture is caring for the environment. Character caring for the environment is an attitude and action that always strives to prevent damage to the surrounding natural environment, and develops efforts to repair natural damage that has occurred.

One of the noble characters that occurs in the culture of the people in the village of Tenganan Pagringsingan Karangasem is that there is local wisdom related to customs, one of which is marriage, the most trendy and a spectacle of tourism is the mageret pandan event held every fifth month in balinese calendar "interview with Ketut Pancawan as staff Kebendesaan on January 27, 2019 ". In this study researchers looked to the uniqueness of the people of Tenganan Banjar Tengah and Banjar Kauh who were married to local communities with outsiders who were widows. When the local community married a wife from outside the village of Tenganan who was a widow, they would be banished to Banjar Pande, so that Banjar Pande up to now was called Banjar Buangan.

\section{METHODOLOGY}

The method is used to support the research process or the course of research, starting from preparation, and implementation until the research ends and producing a scientific work that is recognized as true. The types of data collected in this study were qualitative data and supported by quantitative data.

Qualitative data are data that were stated not in the form of numbers, but in the form of sentences, statements, or descriptions that are sourced from informants, such as traditional leaders, religious leaders, and several school children in Tenganan Village (natural conditions), and more data collection techniques in participant observation, in-depth interviews and documentation $[3,4]$. 
The data analysis technique that was suitable to be used for descriptive type was descriptive technique through three activity lines, namely (1) data collection, (2) data reduction, (3) data presentation, and (4) conclusion or verification. From the results; observation, interview, and documentation were still in the raw form, then the data will then be selected and sorted, then will be presented using sentences and the final conclusions were made.

\section{RESULT AND DISCUSSION}

Strengthening local wisdom in Tenganan Pagringsingan can be sustained to date based on early character education that is non-formal in nature, where parents in the villages of Tenganan Pagringsingan Banjar Kauh and Banjar Tengah have educated their children through speech and messages, which refers to the awig-awig Tenganan traditional village where in awig-awig there is an order that regulates the social life of the local community and sanctions against the awig-awig violator.

Non-formal character education is held as a balance between potential and science, which emphasizes in improving the quality of human resources in Tenganan village. Non-formal character education is also emphasized because National education, namely formal education, is almost certainly not fully capable of carrying out and overcoming the process of improvement quality of human resources.

In the focus of improving the quality of human resources through self-actualization, nonformal education is a means of developing character which will later be able to grow a compatible personality [5]. One form of non-formal education that forms the basis of character education: morality or character of the community of Tenganan Pagringsingan and its survival in awig-awig tradition that has been inherited by its predecessors.

Resilience in a local tradition can be done during childhood which is a pleasant time. Puppies will feel happy when they meet, gather with children who are of the same age as the places that are available to the community. In the Tenganan traditional village environment they meet in the long bale in the middle of the village to be educated by community leaders to be able to maintain their traditions as a local wisdom.

Until now the problems in Tenganan Karangasem village related to the strengthening of local wisdom still persist, so that non-formal character education is very much needed in addition to character education obtained in formal schools, because schools have not guaranteed being able to overcome overall character education given the time available in school is quite limited. Besides that informal education is the main education in shaping character education in children towards formal education [6].

Strengthening local wisdom in the village of Tenganan Pagringsingan in addition to being a traditional village community structure, the village of Tenganan is also a base of tourism villages. The development of tourism villages in the village area of Tenganan has resulted in much progress, this has been proven to develop rapidly in the area of Candi Dasa. To make the village of Tenganan as a tourist destination village that can involve the public and also have an impact on the community, then it is not as easy as reversing the palm, but must be able to develop several aspects, among others; (a) attraction, b) accessibility, c) amity, and d) ancillary (institutional). Therefore, in order to build tourist villages in Tenganan village, four aspects should be considered and can be well developed.

If you see the development of tourism village in the Tenganan area, it must be supported by the potential of existing natural tourism and cultural tourism. But if we look further, then there is one tradition that becomes the icon of the Tenganan area which is a very strong 
cultural-based local wisdom to maintain by the community through character education as a tradition. Tradition that still exist in the village of Tenganan Pagringsingan is mageret pandan carried out by men and their social life system in the form of tenun pagringsingan and marriage. If the Tenganan traditional village refers to cultures such as mageret pandan, tenun pagrinsingan, and marriage which are usually carried out following local traditions, the Tenganan community also has a performance room (note outcome) that can be packaged as a tourism product.

The phenomenon in the field now shows that the strengthening of culture-based local wisdom still exists, but the influence of globalization cannot be avoided, this is evident in the association of young people who have worked outside their village automatically who have been exposed to outside influences to enter the village collaborating in local culture, so that from the order of social life it is not like in ancient times. For the strength of a local wisdom or tradition, the cultivation of life values can be done through character education [7-9]. While what is expected by the local community is the local wisdom which is a noble inheritance that is closely related to the values of life. The values of life are united not only in the form of religion, but also in the form of culture and customs. Ancestral heritage as local wisdom should be maintained through character education carried out by parents and community leaders and continued in formal education.

\subsection{A form of cultural-based local wisdom reinforcement through character education in school children. Forms of reinforcing local wisdom include: mutual cooperation, exemplary, professional, and independence.}

Mutual cooperation is a joint effort by community leaders in achieving the goal of maintaining cultural values based on local wisdom. Mutual cooperation is cooperation when someone realizes that they have a common interest. Cooperation requires the goals to be achieved, well. Cooperation will be stronger if there are very difficult challenges that must be given a solution. Forms of strengthening in mutual cooperation are harmony, loyalty, and ownership.

Exemplary is a way that religious leaders and community leaders can do in providing guidance to strengthen local wisdom as a value of community life which is regulated in an awig-awig (customary regulation). The example of society is "leading by example; being a model, role modeling" (acting as an example). Community leaders and religious leaders who play exemplary roles become a real symbol of what they expect their followers to achieve.

Professional, is a form of strengthening in fostering school children through maintaining, caring for, training, teaching, guiding, and leading in maintaining local wisdom. However, the community referred to here is a human figure as a role model, who in various fields has advantages and privileges because have qualified as religious leaders and community leaders.

Independence is an attitude or behavior and mentality that allows religious leaders and community leaders to act in conducting coaching in the community freely, and beneficially, by trying to do things honestly, true to their own encouragement, in accordance with their duties and obligations as community leaders, so that it can provide guidance that is very beneficial for the lives of school children in the village of Tenganan Karangasem. Characteristics of independence among others; (1) have the ability to always try and have initiative, (2) have the ability to carry out tasks and responsibilities, and (3) have the ability to solve all problems that exist in the community. 


\subsection{The process of instilling character values in school children to strengthen local wisdom.}

The process of planting character values for children carried out by community leaders and religious leaders was carried out with the concept of community-based Hindu religious teachings contained in the teachings of Tri Hita Karana. The aim is to improve sradha bhakti and to instill moral values, and strengthen cultural-based local wisdom as the inheritance of their ancestors $[10,11]$.

The process of organizing the cultivation of character values in school children is considered very important in an effort to improve the quality of religious education and Hindu religious education and change the behavior of human resources, so that it becomes more dynamic, explorative in increasing knowledge and insight and improving village-oriented tourism [12].

\section{CONCLUSION}

Reinforcement of local wisdom in Tenganan Pagringsingan can be sustained to date based on early character education that is non-formal in nature, where parents in the villages of Tenganan Pagringsingan Banjar Kauh and Banjar Tengah have educated their children through speech and messages. which refers to the awig-awig Tenganan traditional village where in awig-awig there is an order that regulates the social life of the local community and sanctions against the awig-awig violator.

Reinforcement of local wisdom in the village of Tenganan Pagringsingan in addition to being a traditional village community structure, the village of Tenganan is also a base of tourism villages. The development of tourism villages in the village area of Tenganan has resulted in much progress this has proven tourism to develop rapidly in the Candi Dasa area. To make the village of Tenganan as a tourist destination village that can involve the public and also have an impact on the community, then it is not as easy as turning the palm of the hand, but must be able to develop several aspects including; (a) attraction, b) accessibility, c) amity (facility), and d) ancillary (institutional). Therefore, in order to build tourist villages in Tenganan village, four aspects should be considered and can be well developed.

Cultural forms of local wisdom reinforcement through character education in school children. Forms of strengthening local wisdom include: mutual cooperation, exemplary, professional, and independence. The process of instilling character values in school age children to strengthen local wisdom. The process of planting character values in children carried out by community leaders and religious leaders was carried out with the concept of community-based Hindu teachings contained in the teachings of Tri Hita Karana.

\section{REFERENCES}

[1]. W. Gunawan. Pendidikan Karakter Berbasis Kearifan Lokal di Sekolah.Yogyakarta: Pustaka Pelajar, 2015.

[2]. W. Agus. Pendidikan Karakter Usia Dini. Strategis Membangun Karakter di Usia Emas. Yogyakata: Pustaka Pelajar, 2012.

[3]. Sugiyono. Metode Penelitian Kuantitatif Kualitatif dan $R \& D$. Bandung: Alfabeta, 2017.

[4]. Subagyo. Metode Penelitian Pendidikan dan Pengembangan.Jakarta: Prenadamedia Group, 2007. 
[5]. Mulyadi. "Pengaruh Kearifan Lokal, Locus Of Control dan Motivasi Terhadap Perilaku Berwawasan Lingkungan Petani dalam Menglola Lahan Pertanian di Kabupaten Soppeng", Jurnal Manusia dan Lingkungan Hidup, Vol. 18, No. 1 pp. 60-67, 2011.

[6]. Mastiningsih, G..A. G. Eka. "Pelestarian Subak dalam Upaya Pemberdayaan Kearifan Lokal Menuju Ketahan Pangan”. Bumi Lestari Journal of Envirenment, Vol. 12, No. 2, 2012.

[7]. Sulistianingsih. Jurnal Mengkaji Nilai-nilai Kearifan Lokal Jawa dalam Pembentukan Hukum. 2017.

[8]. Suarta. Jurnal Mengkaji Membangun Pendidikan Karater Kearifan Lokal, 2012.

[9]. Wagiran. "Pengembangan Karakter Berbasis Kearifan Lokal". Jurnal Pendidikan Karakter, October 2012.

[10]. I. Ery. Jurnal Mengkaji Orientasi Pendidikan Karakter Berbasis Kearifan Lokal Makasar, 2017.

[11]. Supadi. "Model Pengelolaan Irigasi Memperhatikan Kearifan Lokal". Journal Media Komunikasi Teknik Sipil, No. 3, pp. 269-278, 2008.

[12]. K. Saddhono, S. T, Widodo, M. T. Al Makmun, and M. Tozu, "The study of philosophical meaning of batik and kimono motifs to foster collaborative creative industry." Asian Soc. Sci. vol. 10 no. 9 pp 52-61, 2014 